\title{
Anti-hypercholesterolemic effect of milk produced from quaffing dairy goats with linseed oil on lipid profile of albino rats
}

\author{
M. A. Ali ${ }^{1,}{ }^{*}$, M. Sh. Thabet ${ }^{1}$ and E. M. Ibrahim ${ }^{2}$ \\ ${ }^{1}$ Dairy Department, Faculty of Agriculture, Al-Azhar University, Cairo, Egypt \\ 2 Sheep and Goats Research Department, Animal Production Research Institute, Agriculture Research \\ Center, Giza, Egypt \\ * Corresponding author E-mail: DR.Mansourabdou@azhar.edu.eg (M. Ali).
}

\begin{abstract}
The aim of the present study is to evaluate the effect of modified milk production from goats administrated different amounts of flaxseed oil on serum lipid profile of rats. Twenty-five mature Albino rats were randomly and equally divided into five groups, five rats each. The rats were acclimatized on basal diet for 7 days before starting the experiment. The first group was fed on basal diet and served as control I, the second group was offered basal diet plus normal goat milk (control II), while the rest three groups were fed on basal diet plus milk from goats received 10, 20 and $30 \mathrm{~mL}$ flaxseed oil/head/day. Results of serum analysis revealed that serum triglycerides concentrations reduced by $1.42,6.57$ and $14.10 \%$ in tested groups G1, G2 and G3 respectively, compared to control II. Moreover, total cholesterol levels were linearly decreased after 28 days of feeding, with reduction values varied from 1.39 to $9.10 \%$ with a mean value of $5.48 \%$ for treated group, compared to control II. Continuously, LDL-cholesterol levels were decreased by 13.81 and 16.49 in G2 and G3 group respectively, as compared with control II. While no significant was detected for G1 group. However, the same trend of result was also true for VLDL-cholesterol levels. In contrary, at the end of experiment, the levels of HDL-cholesterol as "antiatherogenic" index were increased in all treatments compared to their corresponding initial values. In conclusion, flaxseed oil can be used as nutritional supplement to lactating goats to reduce saturated fatty acids and increase polyunsaturated fatty acids in the resultant milk.
\end{abstract}

Keywords: Goat; linseed oil; Cholesterol.

\section{INTRODUCTION}

Goats milk has an extra special dietary and sensory properties, for which it is prized in many countries. Goats milk contain relatively higher amount of saturated fats than most oils of plant origin. The consumption of saturated fats is often associated with health disorders in man, such as coronary heart disease (Pfeuffer, 2001). However, the high fat content in goat milk might limit the demand for milk and milk product by health-conscious consumers.

Moreover, American Heart Association (AHA) reported that hypercholesterolemic and hyperlipidemia has been ranked as one of the greatest risk factors contributing to the prevalence and severity of coronary heart diseases. Thus, it is considered that keeping blood cholesterol at a desirable level is one of the major preventive strategies for these diseases. Therefore, much attention has been given to the relationship between diet and blood cholesterol levels, as well as improving serum lipids by the intake of modified diets.
Continuously, feeding oilseeds and vegetable oil have been recommended as dietary supplements because of their hypocholesterolaemic effect.

However, feeding flaxseed oil to dairy goats had been found to reduce the concentrations of short-chain and saturated fatty acids and increased concentrations of long-chain and poly unsaturated fatty acids.

Therefore, the objective of the current investigation was to determination the influence of modified milk produced from quaffing flaxseed oil to dairy goats on plasma lipid of albino rats.

\section{MATERIALS AND METHODS}

\section{Materials}

\section{Albino rats}

Twenty-five mature albino rates, with mean body weights of $130 \pm 5 \mathrm{gm}$. obtained from Animal house, National Research Center, Dokki, Cairo, Egypt, were used in the present study. 


\section{Rats basal diet}

The chemical composition of rat's basal diet was: raw protein, $23 \%$; raw fat, $3.40 \%$; fibers, $3.60 \%$, starch, $62 \%$ and ash $8 \%$.

\section{Blood samples}

Blood samples were collected on the beginning and the end of the experiment. Blood samples were drawn from the retrobulbar venous plexus of each rat through a heparinized capillary glass tubes and left to clot at room temperature to obtain a clear serum. While, at the end of experiment, the rats were killed by withdrawing blood from the abdominal aorta under light diethyl ether anesthesia. Blood were collected heparin added tubes.

\section{Methods:}

\section{Biological Assay}

Biological study was carried out in Animal House Lab, Department of Animal Production; Faculty of Agriculture, AlAzhar University, Cairo, Egypt.

Rats were housed in stainless steel cages under ambient temperature conditions $\left(20 \pm 5^{\circ} \mathrm{C}\right)$ for 28 days and allowed to acclimatize for a period of 7 days prior to experiment start.

Rats were randomly and equally divided into five groups, five rats each. Groups were fed as follows:

${ }^{*}$ Group (1) was fed on basal diet $(70 \mathrm{~g} / \mathrm{d})$ and served as control.

*Group (2) was fed on basal diet containing control milk from goats nil flaxseed oil.

${ }^{*}$ Group (3) was fed on basal diet containing milk from goats administrated $10 \mathrm{~mL}$ flaxseed oil.

${ }^{*}$ Group (4) was fed on basal diet containing milk from goats administrated $20 \mathrm{~mL}$ flaxseed oil.

${ }^{*}$ Group (5) was fed on basal diet containing milk from goats administrated $30 \mathrm{~mL}$ flaxseed oil.

Rats were weighed at the beginning and the end of the experimental period.

\section{Determination of total cholesterol}

The total cholesterol concentration was determined in the serum using Bio Med diagnostic kit, and the concentration was calculated by using the following equation:

Cholesterol $(\mathrm{mg} / \mathrm{dL})=\frac{A \text { of the tested sample }}{A \text { of the standard solution }} \times 200$

Where: $\mathrm{A}=\mathrm{Absorbance}$ at $546 \mathrm{~nm}$.
Determination of high density lipoproteins (HDL) cholesterol

HDL-cholesterol was determined in the serum by using Bio Med diagnostic kit, the HDL-concentration was calculated by using the following equation:

HDL-cholesterol $(\mathrm{mg} / \mathrm{dL})=$ A sample $\times 325$ Where: $A=$ Absorbance at $546 \mathrm{~nm}$.

\section{Determination of low density lipoproteins (LDL) cholesterol}

The LDL-cholesterol was estimated according to the formula of Beena and Prasad (1997) as follows: LDL-cholesterol (mg/dL)

$=$ Total cholesterol $\quad\left(\right.$ HDL $\left.+\frac{\text { triglyc } \_ \text {rides }}{\mathbf{5}}\right)$

\section{Very low density lipoprotein (VLDL) cholesterol}

VLDL-cholesterol level was calculated by using the formula of Fridewald et al. (1972) as follows:

VLDL-cholesterol=Triglyceride/5.

\section{Determination of triglycerides}

The triglycerides concentration was determined in serum by using Bio Med diagnostic kit. The triglycerides concentration was calculated using the following equation: Triglycerides (mg/dL)

$$
=\quad \frac{A \text { of the tested sample }}{A \text { of the standard solution }} \times 200 \text {. }
$$

Where: $A=$ Absorbance at $500-550 \mathrm{~nm}$.

\section{Calculation of atherogenic indexes}

The atherogenic indexes were calculated as follows:

Atherogenic index 1= LDL-cholesterol / Total cholesterol

Atherogenic index $2=$ (Total cholesterol HDL) / HDL

\section{Biological evolution of rat diets}

Biological evolution of the different diets was carried out according to Carthew et al. (2001) by using following formulas: Body weight gain $=$ final weight - initial weight

Growth rate, g/day $=\frac{\text { Body weight gain, }(\mathrm{g})}{\text { Experiment } \mathbf{I} \text { period long, (days) }}$

Food efficiency ratio $=$ Growth rate, $\mathrm{g} /$ day $\div$ food intake $\mathrm{g} /$ day. 


\section{Statistical analysis}

The data obtained from three replicates were analyzed by (ANOVA) using the SPSS statistical package program, and differences among the means were compared using the Duncan's Multiple Range test (SPSS, 1998), a significant level of 0.05 was chosen.

\section{RESULTS AND DISCUSSION}

It has been recognized that inclusion of saturated fats of animal origin diet often associated with increased risk of cardiovascular diseases (Ioyce et al., 2009). However, revealed serum cholesterol level "hypercholesterolemia" as a result of consumption unhealthy diet such as those high in fat (saturated fatty acids), salt and free sugar are one of the most important risk factors for atherosclerosis and subsequent cardiovascular diseases (Steinberg, 2002 and WHO, 2003). Thus, diet low in saturated fats and rich in unsaturated fats, including omega-3 fatty acid, can reduce serum cholesterol and heart diseases. In this respect, several studies have been reported that unsaturated fats can be increased in ruminant products by supplementation with vegetable oils (Abu- Ghzaleh and Holmes, 2007 and Bernard et al., 2009). Oil seeds are rich in PUFA, which can feed to dairy animals to modify the milk fatty acids profile and produce amore nutritionally beneficial milk for human consumption (Kennely, 1996).

Therefore, the current study aimed to define the effect of resultant milk of quaffing dairy goats with linseed oil on serum lipid profiles of albino rats.

The effect of the experimental diets on growth parameters of tested rats are presented in Table 1. It was obvious from these data that rats received goat's milk gained higher body weights than those fed only dry diet. Also, rats fed on resultant milk from goat's received $10 \mathrm{~mL}$ flaxseed oil/day (group G1) gained the highest final body weight, being $212 \mathrm{~g}$. The same trend of results was previously reported by Mohamed and Afifi (2011) and Boulbaroud et al. (2012). Additionally, the present results revealed that there was no considerable variation between growth rate and food efficiency among different treatments. These results agree with those reported by El-Wasieif (2008) and Mohamed and Afifi (2011).

Continuously, results of total cholesterol and HDL-cholesterol were summarized in Table 2 and Fig. 1. It could be noticed from these results that, at the end of the experiment, serum cholesterol level of rats in control II was increased by $10.63 \%$ compared to those in control I (dry diet). Moreover, the total serum cholesterol was lowered by $1.39,5.95$ and $9.10 \%$ in rats fed on resultant milk from goats received 10, 20 and $30 \mathrm{~mL}$ flaxseed oil/day, respectively, as compared with those in control II. The same finding was previously mentioned by Lucas et al. (2004) and Soltan (2012). However, the lowering effect of flaxseed oil may be due to increase Omega-3 long chain polyunsaturated fatty acid in rats by conversion of ALA in flaxseed oil to EPA and DHA (Moghadasian, 2008 and Tzang $e t$ al., 2009).

Also, from the same table, it could be observed that serum HDL- cholesterol levels were increased at the end of the experiment, where the increases \% varied from 5.17 to $18.85 \%$ as compared with their corresponding initial values. Furthermore, rats consumed milk from goats received 20 $\mathrm{ml}$. flaxseed oil/ day ranked the highest increase \%, actually $12.10 \%$ followed those fed milk from goats received $10 \mathrm{~mL}$. flaxseed oil/day being $11.24 \%$. However, HDL levels are "anti-atherogenic" while reduced levels are associated with increased risk for coronary artery disease (Zilva and Mayne, 1991). These results are agreement with those reported by Boulbaroud et al. (2012), El- sahar and abed El -Rahman (2014) and Aly-Aldin et al. (2015).

Furthermore, the levels of serum triglycerides, LDL and VLDL-cholesterol were presented in Table 3 and Fig 2-4. It was evident from the data obtained that rats consumed only goats milk (control II) possessed greatly increase in serum triglycerides by about $6.56 \%$ as compared to control I (dry diet). In contrast the levels of serum triglycerides in rats fed on resultant milk from goats received different amounts of flaxseed oil were lower than those fed on goats milk (control II). However, the reduction in triglycerides levels 1.42, 6.57 and $14.10 \%$ for G1, G2 and G3 groups, respectively. 
These results are in agreement with those mentioned by Riediger et al. (2008), ElSahar and Abd El-Rahman (2014), Khan and Makki (2017). In this respect, De Caterina et al. (2007), reported that n-3 fatty acids reduced plasma TG. N-3. Fatty acids suppressed hepatic lipogenesis and reduced circulating triglycerides levels. Also, Soltan (2012) concluded that the main effect of dietary n-3 fatty acids on plasma lipids and lipoproteins in general is reduction in plasma triglycerides by 20 $50 \%$ in healthy subject and even more in subjects with hypertriglyceridemia.

Since a high blood LDL- cholesterol is associated with increased risk of atherosclerosis and cardiovascular disease, any product that lowers this level is of potential value. As $70 \%$ of total cholesterol is HDL-cholesterol (Robbins and Cortan, 1981).

Therefore, the effect of feeding resultant milk from goats received different concentrations of flaxseed oil on rat's LDLcholesterol was carried out. From results summarized in Table 3 and Fig. 2, 3 and 4, it appeared that goats milk (control II) markedly increase LDL-cholesterol by $15.5 \%$ as compared to control I (dry diet). In contrary, rats in groups 2 and 3 (goats received 20 and $30 \mathrm{~mL}$. flaxseed oil/day) ranked lower LDL-cholesterol levels by $13.81 \%$ and $16.49 \%$ respectively, as compared to control II. While, rats in group I showed non-significant difference in their LDL-cholesterol levels. These results are consistent with previous finding by Vijaimohan et al. (2006); Boulbaroud et al. (20102) and Kawakami et al. (2015).

With increasing serum level of LDLcholesterol, the scavenger cells taken up larger amounts of circulating lipoprotein and become overloaded with cholesterol named "foam cells", thos cells become the atherosclerotic plague (Zilva and Mayne, 1991). Reduction in the removal of LDL from serum causes elevated serum levels of LDL and increased uptake of LDL by macrophages and smooth muscle cells deposits in arterial walls and consequently, premature atherosclerosis (Tietz, 1986). In general, for each $1 \mathrm{mg} / \mathrm{dl}$ decrease in LDLcholesterol in the plasma there is approximately a $2 \%$ decrease in mortality from atherosclerotic heart disease.

Continuously, the obtained results indicate that level of serum VLDL-cholesterol in control II was significantly higher than control I, by $6.59 \%$ at the end of the experiment. As compared with group fed on resultant goats' milk (control II), the VLDL-cholesterol levels were lowered by $1.42,6.57$ and $14.10 \%$ in groups G1, G2 and G3 respectively. However, this reduction may be attributed to the reduction in serum total cholesterol. Generally, our results are in complete agreement with those of Morise et al. (2004); Vijaimohan et al. (2006) and Fadlalla et al. (2013).

Generally, the decrease in serum triglyceride, LDL and VLDL of different treatments (G1 - G3) can be explained as Strolien et al. (2007) previously mentioned, the authors suggested that the decrease in triglyceride levels attributed to the lowering effect of omega-3 fatty acids has been mainly ascribed to reduce hepatic synthetic of VLDL. Omega-3 fatty acid suppressed hepatic lipogenesis and reduced circulating TG level.

As a matter of fact, the atherogenic index is an indication for the susceptibility for atherosclerosis. Therefore, the atherogenic indices in tested rats, also the ratio between LDL or HDL-cholesterol and total cholesterol, in addition to LDL/HDL ratio were calculated and data obtained were presented in Table 4. It is clear from these results that, rats fed on goat's milk (control II), led to obvious increases in atherogenic indexes 1 \& 2 , in addition in LDL/HDL ratio by a mean values of $4.48,2.81$ and $5.72 \%$ respectively, while lowered HDL/total cholesterol ratio by $1.27 \%$ as compared to those received dry diet (control I).

Continuously, the results from the same table revealed that in G2 and G3 groups, the values of atherogenic indexes and LDL/HDL ratio were decreased by (8.25, 10.11 , and $12.59 \%$ ) and (7.92, 12.49 and $13.40 \%$ ), while HDL/total cholesterol ratio were increased by 4.79 and $6.08 \%$ respectively, as compared to control II. In contrast, for group $\mathrm{G} 1$, the previous values of atherogenic indexes and LDL/HDL ratio were increased by 2.64, 3.21 and $4.05 \%$ respectively, while HDL/ total cholesterol was decreased by $1.47 \%$ as compared with corresponding value of control II. Similar trend of result was previously reported by Dupasquier et al. (2007) and Gruenfelder (2014), the authors demonstrated that dietary flaxseed can inhibit atherosclerosis through a reduction of circulating cholesterol levels. 


\section{CONCLUSION}

In conclusion, flaxseed oil can be used as nutritional supplement to lactating goats to reduce saturated fatty acids and increase polyunsaturated fatty acids in the resultant milk. Moreover, the obtained results strongly suggest that the resultant milk showed a pronounced hypolipidemic effect, as reduced serum cholesterol, triglycerides, LDL and VLDL-cholesterol, as well as increase the HDL- cholesterol levels in blood serum in albino rats.

\section{REFERENCES}

Abu-Ghazaleh, A.A., Holmes, L.D., 2007. Diet supplementation with fish oil and sunflower oil to increase conjugated linoleic acid levels in milk fat of partially grazing dairy cows. J. Dairy Sci., 90 (6), 2897-2904.

Aly-Aldin, M.M., Mansour, E.H., Rahma, E.H., Abo El-Fath, A.E.E., El-Bedawey, F.A., El-Habashy, M.M., 2015. Protective role of flaxseed oil on hypercholesterolemic rats. Biolife 3(4), 794-801.

Beena, A., Prasad, B., 1997. Effect of yoghurt and bifidus yoghurt fortified with skim milk powder, condensed whey and lactose-hydrolyzed condensed whey on serum cholesterol and triacylglycerols level on rats. J. Dairy Res., 64 (3), 453-457.

Bernard, L., Bonnet, M., Leroux, C., Shingfield, K.J., Chilliard, Y., 2009. Effect of sunflower-seed oil and linseed oil on tissue lipid metabolism, gene expression, and milk fatty acid secretion in alpine goats fed maize silage-based diets. J. Dairy Sci., 92 (12), 6083-6094.

Boulbaroud, S., El-Hessni, A., Azzaoui, F.Z., Mesfioui, A., 2012. Sesame seed oil and flaxseed oil affect plasma lipid levels and biomarkers of bone metabolism in ovariectomized Wistar rats. Biol. Med., 4 (3), 102.

Carthew, P., Baldrick, P., Hepburn, P.A., 2001. An assessment of the carcinogenic potential of shea oleine in the rat. Food Chem. Toxicol., 39 (8), 807815.

De Caterina, R., Madonna, R., Bertolotto, A., Schmidt, E.B., 2007. N-3 fatty acids in the treatment of diabetic patients. Diabetes Care, 30 (4), 1012-1026.

Dupasquier, C.M., Dibrov, E., Kneesh, A.L., Cheung, P.K., Lee, K.G., Alexander, H.K., Pierce, G.N., 2007. Dietary flaxseed inhibits atherosclerosis in the LDL receptor-deficient mouse in part through antiproliferative and anti-inflammatory actions. Am. J. Physiol. Heart Circul. Physiol., 293 (4), 2394-2402.

EL-Sahar, E.G.E., Abed EL-Rahman, A.M.M., 2014. Study on the biological effect of use flaxseed oil as a source of fat on the Biomarkers of experimental rats. J. Am. Sci., 10 (3), 116-123.

EL-Waseif, M.A.E., 2008. Chemical study on pure linseed oil. MSc Thesis, Fac. Agric. Al-Azhar Univ. Cairo, Egypt.

Fadlalla, E.A.S., Abd Elal, Z.S., Seddik, A.A., 2013. Protective effect of olive, almond and flaxseed oil against carbon tetrachloride-induced hepatotoxicity in rat models. Afr. J. Biol. Sci., 6 (1), 243-259.

Friedewald, W.T., Levy, R.I., Fredrickson, D.S., 1972. Estimation of the concentration of low-density lipoprotein cholesterol in plasma, without use of the preparative ultracentrifuge. Clin. Chem., 18 (6), 499-502.

Gruenfelder, C.A., 2014. Sensory evaluation of hearthealthy foods enriched with omega-3 fats from fish oil. PhD Thesis, College of Saint Elizabeth.

Joyce, T., Wallace, A.J., McCarthy, S.N., Gibney, M.J., 2009. Intakes of total fat, saturated, monounsaturated and polyunsaturated fatty acids in Irish children, teenagers and adults. Public Health Nutr., 12 (2), 156-165.

Kawakami, Y., Yamanaka-Okumura, H., NaniwaKuroki, Y., Sakuma, M., Taketani, Y., Takeda, E., 2015. Flaxseed oil intake reduces serum small dense low-density lipoprotein concentrations in Japanese men: a randomized, double blind, crossover study. Nutr. J., 14 (1), 39.

Kennelly, J.J., 1996. The fatty acid composition of milk fat as influenced by feeding oilseeds. Anim. Feed Sci. Technol., 60 (3), 137-152.

Khan, S.A., Makki, A., 2017. Dietary changes with omega-3 fatty acids improves the blood lipid profile of Wistar Albino rats with hypercholesterolaemia. Int. J. Med. Res. Health Sci., 6 (3), 34-40.

Lucas, E.A., Lightfoot, S.A., Hammond, L.J., Devareddy, L., Khalil, D.A., Daggy, B.P., Arjmandi, B.H., 2004. Flaxseed reduces plasma cholesterol and atherosclerotic lesion formation in ovariectomized Golden Syrian hamsters. Atherosclerosis, 173 (2), 223-229.

Moghadasian, M.H., 2008. Advances in dietary enrichment with n-3 fatty acids. Crit. Rev. Food Sci. Nutr., 48 (5), 402-410.

Mohamed, M.S., Afifi, A.A., 2011. Effect of some polyunsaturated fatty acids rich-oils on plasma lipid profiles using normal rats. J. Agric. Chem. Biotechnol., Mansoura Univ. (2), 49-59.

Morise, A., Sérougne, C., Gripois, D., Blouquit, M.F., Lutton, C., Hermier, D., 2004. Effects of dietary alpha linolenic acid on cholesterol metabolism in male and female hamsters of the LPN strain. The J. Nutr. Biochem., 15 (1), 51-61.

Pfeuffer, M., 2001. Physiological effects of individual fatty acids in animal and human body, with 
particular attention to coronary heart diseases risk modulation. Arch. Anim. Breed., 44, 89-98.

Riediger, N.D., Othman, R., Fitz, E., Pierce, G.N., Suh, M., Moghadasian, M.H., 2008. Low n-6: n-3 fatty acid ratio, with fish-or flaxseed oil, in a high fat diet improves plasma lipids and beneficially alters tissue fatty acid composition in mice. Eur. J. Nutr., 47 (3), 153-160.

Robbins, S.L., Cortan, R.S., 1981. The Pathological basis of disease. Philadelphia. PA: W.B. Saunders.

Soltan, S.S.A.M., 2012. The effects of varieties sources of omega-3 fatty acids on diabetes in rats. Food Nutr. Sci., 3 (10), 1404.

SPSS, 1998.Statistical Package for The Social Science for Release 9.0.0, standard version SPSS. Inc.

Steinberg, D., 2002. Atherogenesis in perspective: hypercholesteremia and inflammation as partners in crime. Nat. Med., 8, 1211-1217.

Tietz, N.W., 1986. Methods of determination of ascorbic acid. Text Book of Clinical Biochemistry, WB Saunders Company, USA, pp.960-962.
Tzang, B.S., Yang, S.F., Fu, S.G., Yang, H.C., Sun, H.L., Chen, Y.C., 2009. Effects of dietary flaxseed oil on cholesterol metabolism of hamsters. Food Chem., 114 (4), 1450-1455.

Vijaimohan, K., Jainu, M., Sabitha, K.E., Subramaniyam, S., Anandhan, C., Devi, C.S., 2006. Beneficial effects of alpha linolenic acid rich flaxseed oil on growth performance and hepatic cholesterol metabolism in high fat diet fed rats. Life Sci., 79 (5), 448-454.

WHO, 2003. Integrated Management of Cardiovascular Risk. World Health Organization, Geneva, Switzerland, p.35.

Wu, Z., Huber, J.T., 1994. Relationship between dietary fat supplementation and protein concentration in lactating cows: A review. Livest. Prod. Sci., 39, 141-155.

Zilva, J.F., PR Mayne, P.D., 1991. Clinical chemistry in diagnosis and treatment. $5^{\text {th }}$ ed. ELBS with Edward Arnold, British Government, p. 233.

Table 1. Growth parameters of rats fed on milk from goats received different amounts of flaxseed oil.

\begin{tabular}{lccccc}
\hline \multicolumn{1}{c}{ Treatments } & $\begin{array}{c}\text { Cont. I } \\
\text { dry diet }\end{array}$ & Cont. II & G1 & G2 & G3 \\
\hline Parameters & 133 & 137 & 137 & 137 & 137 \\
Finitial body weight $(\mathrm{g})$ & $172^{\mathrm{C}}$ & $196^{\mathrm{B}}$ & $212^{\mathrm{A}}$ & $208^{\mathrm{A}}$ & $207^{\mathrm{A}}$ \\
\% change to normal $(\mathrm{g})$ & $-\mathrm{y}^{\mathrm{A}}$ control & 13.95 & 23.26 & 20.93 & 20.35 \\
Food intake (g/day) & 14 & 14 & 14 & 14 & 14 \\
Body weight gain (g) & 39 & 59 & 75 & 71 & 70 \\
Body weight gain (\%) & 29.3 & 43.07 & 54.74 & 51.82 & 51.09 \\
Growth rate (g/day) & $1.39^{\mathrm{B}}$ & $1.54^{\mathrm{B}}$ & $1.96^{\mathrm{A}}$ & $1.85^{\mathrm{A}}$ & $1.82^{\mathrm{A}}$ \\
Food efficiency & 0.1 & 0.11 & 0.14 & 0.13 & 0.13 \\
\hline
\end{tabular}

The means within the same row having different superscript are significantly varied $(P \geqslant 0.05)$.

Means with the same letter are not significantly different.

Cont.I: control dry diet, Cont.II: control goat's milk, G1: milk from goats received $10 \mathrm{~mL}$ flaxseed oil /day.

G2: milk from goats received $20 \mathrm{~mL}$ flaxseed oil /day, G3: milk from goats received $30 \mathrm{~mL}$ flaxseed oil /day.

Table 2. Levels of serum total cholesterol and HDL-cholesterol in rats fed milk goats received different amounts of flaxseed oil:

\begin{tabular}{lccccc}
\hline \multicolumn{1}{c}{ Treatments } & $\begin{array}{c}\text { Cont. I } \\
\text { dry diet }\end{array}$ & Cont. II & G1 & G2 & G3 \\
\hline Initial total cholesterol (mg/dL) & 85.34 & 85.14 & 86.61 & 85.81 & 87.02 \\
Final total cholesterol (mg/dL) & $91.31^{\mathrm{C}}$ & $101.02^{\mathrm{A}}$ & $99.62^{\mathrm{A}}$ & $95.01^{\mathrm{B}}$ & $91.83^{\mathrm{C}}$ \\
\% change to normal control & $(-) 9.61$ & ------ & $(-) 1.39$ & $(-) 5.95$ & $(-) 9.10$ \\
Initial HDL-cholesterol (mg/dL) & 47.75 & 46.16 & 47.94 & 48.26 & 48.2 \\
Final HDL-cholesterol (mg/dL) & $50.22^{\mathrm{B}}$ & $54.86^{\mathrm{A}}$ & $53.33^{\mathrm{A}}$ & $54.10^{\mathrm{A}}$ & $52.91^{\mathrm{A}}$ \\
$\%$ change to normal control & $(-) 8.45$ & ----- & $(-) 2.79$ & $(-) 1.39$ & $(-) 3.55$ \\
\hline
\end{tabular}

The means within the same row having different superscript are significantly varied $(P \geqslant 0.05)$.

Means with the same letter are not significantly different.

Cont.I: control dry diet, Cont.II: control goat's milk, G1: milk from goats received $10 \mathrm{~mL}$ flaxseed oil /day.

G2: milk from goats received $20 \mathrm{~mL}$ flaxseed oil /day, G3: milk from goats received 30mL flaxseed oil /day. 
Table 3. Levels of serum triglycerides, LDL-cholesterol and VLDL-cholesterol in rats fed on milk from goats received different amounts of flaxseed oil:

\begin{tabular}{|c|c|c|c|c|c|}
\hline $\begin{array}{ll} & \text { Treatments } \\
\text { Parameters } & \end{array}$ & $\begin{array}{l}\text { Cont. I dry } \\
\text { diet }\end{array}$ & Cont. II & G1 & G2 & G3 \\
\hline Initial triglycerides (mg/dL) & 68.22 & 67.95 & 68.35 & 66.95 & 68.95 \\
\hline Final triglycerides (mg/dL) & $72.87^{\mathrm{B}}$ & $77.65^{\mathrm{A}}$ & $76.55^{\mathrm{A}}$ & $72.55^{\mathrm{B}}$ & $66.70^{C}$ \\
\hline$\%$ change to normal control & $(-) 6.16$ & -------- & $(-) 1.42$ & $(-) 6.57$ & $(-) 14.10$ \\
\hline $\begin{array}{l}\text { Initial LDL-cholesterol } \\
\text { (mg/dL) }\end{array}$ & 23.95 & 25.39 & 25 & 24.16 & 25.03 \\
\hline Final LDL-cholesterol (mg/dL) & $26.52^{\mathrm{B}}$ & $30.63^{\mathrm{A}}$ & $30.98^{\mathrm{A}}$ & $26.40^{\mathrm{B}}$ & $25.58^{\mathrm{B}}$ \\
\hline$\%$ change to normal control & $(-) 13.42$ & --------- & (+) 1.14 & (-) 13.81 & (-) 16.49 \\
\hline $\begin{array}{l}\text { Initial VLDL-cholesterol } \\
\text { (mg/dL) }\end{array}$ & 13.64 & 13.59 & 13.67 & 13.39 & 13.79 \\
\hline $\begin{array}{l}\text { Final VLDL-cholesterol } \\
\text { (mg/dL) }\end{array}$ & $14.57^{\mathrm{B}}$ & $15.53^{\mathrm{A}}$ & $15.31^{\mathrm{A}}$ & $14.51^{\mathrm{B}}$ & $13.34^{\mathrm{C}}$ \\
\hline$\%$ change to normal control & $(-) 6.18$ & $(+) 6.58$ & $(-) 1.42$ & $(-) 6.57$ & $(-) 14.10$ \\
\hline
\end{tabular}

The means within the same row having different superscript are significantly varied $(P \geqslant 0.05)$.

Means with the same letter are not significantly different.

GI: control dry diet, GII: control goat's milk, G1: milk from goats received 10mL flaxseed oil /day.

G2: milk from goats received 20mL flaxseed oil /day, G3: milk from goats received 30mL flaxseed oil /day.

LDL: low density lipoprotein, VLDL: very low density lipoprotein.

Table 4. Levels of atherogenic indexes in rats fed on milk from goats received different amounts of flaxseed oil.

\begin{tabular}{lccccc}
\hline \multicolumn{1}{c}{ TREATMENTS } & $\begin{array}{c}\text { CONT.IDRY } \\
\text { DET }\end{array}$ & CONT. II & G1 & G2 & G3 \\
PARAMETERS & $0.550^{\mathrm{B}}$ & $0.543^{\mathrm{C}}$ & $0.535^{\mathrm{C}}$ & $0.569^{\mathrm{A}}$ & $0.576^{\mathrm{A}}$ \\
\hline Final HDL/Total cholesterol ratio & $0.290^{\mathrm{B}}$ & $0.303^{\mathrm{A}}$ & $0.311^{\mathrm{A}}$ & $0.278^{\mathrm{C}}$ & $0.279^{\mathrm{C}}$ \\
Atherogenic index 1 & $0.818^{\mathrm{B}}$ & $0.841^{\mathrm{A}}$ & $0.868^{\mathrm{A}}$ & $0.756^{\mathrm{C}}$ & $0.736^{\mathrm{C}}$ \\
Atherogenic index 2 & $52.81^{\mathrm{B}}$ & $55.83^{\mathrm{A}}$ & $58.09^{\mathrm{A}}$ & $48.80^{\mathrm{C}}$ & $4^{\mathrm{C}} .35^{\mathrm{C}}$ \\
\% LDL/HDL & & & & &
\end{tabular}

The means within the same row having different superscript are significantly varied $(P \geqslant 0.05)$.

Means with the same letter are not significantly different.

GI: control dry diet GII: control goat's milk, G1: milk from goats received 10mL flaxseed oil /day.

G2: milk from goats received 20mL flaxseed oil /day, G3: milk from goats received 30mL flaxseed oil /day.

LDL: low density lipoprotein. HDL: high density lipoprotein.

Atherogenic index 1: LDL/Total cholesterol, Atherogenic index 2: (Total cholesterol-HDL)/HDL. 


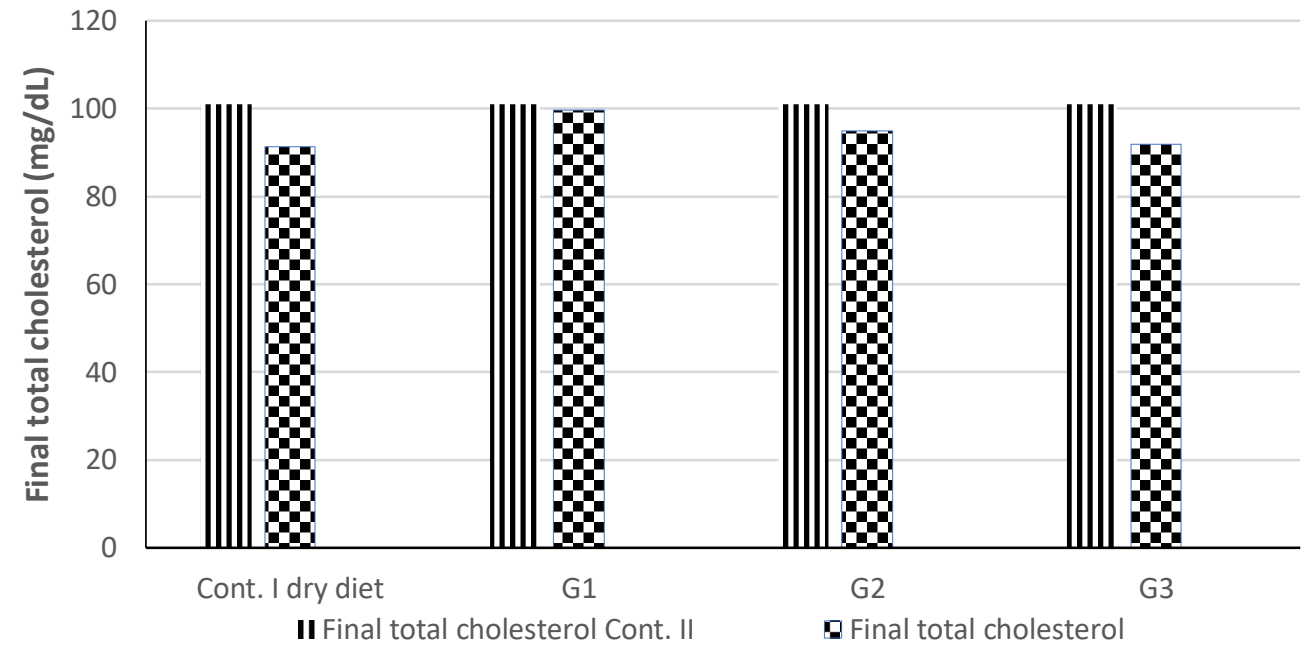

Figure 1. Effect of fed milk goats received different amounts of flaxseed oil on the levels of serum total cholesterol.

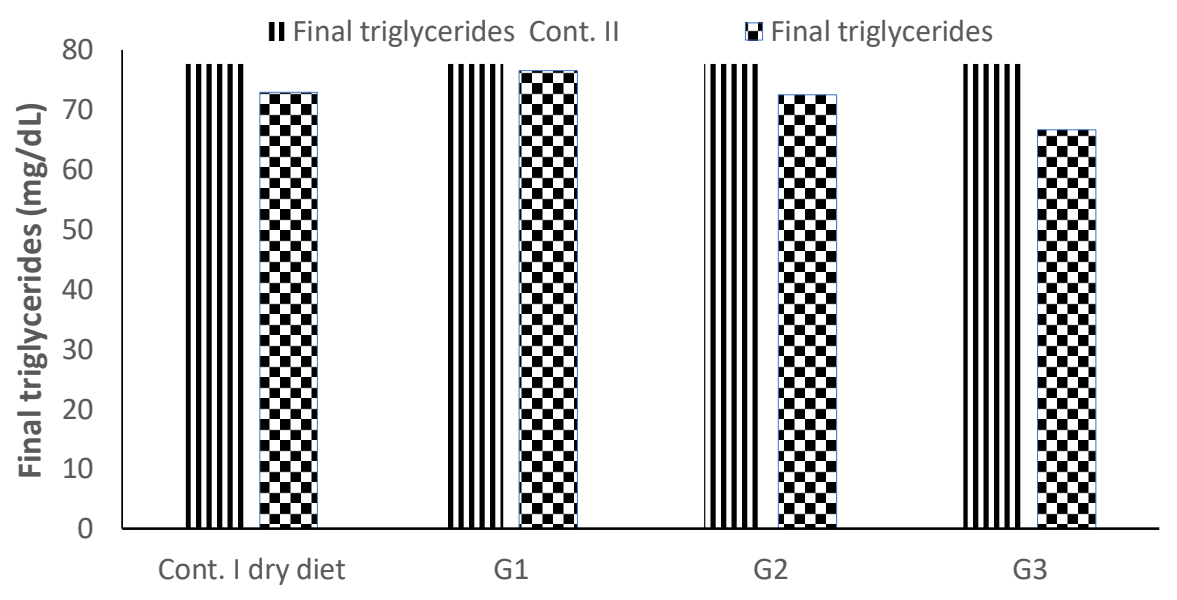

Figure 2. Effect of fed milk goats received different amounts of flaxseed oil on the levels of serum triglycerides. 


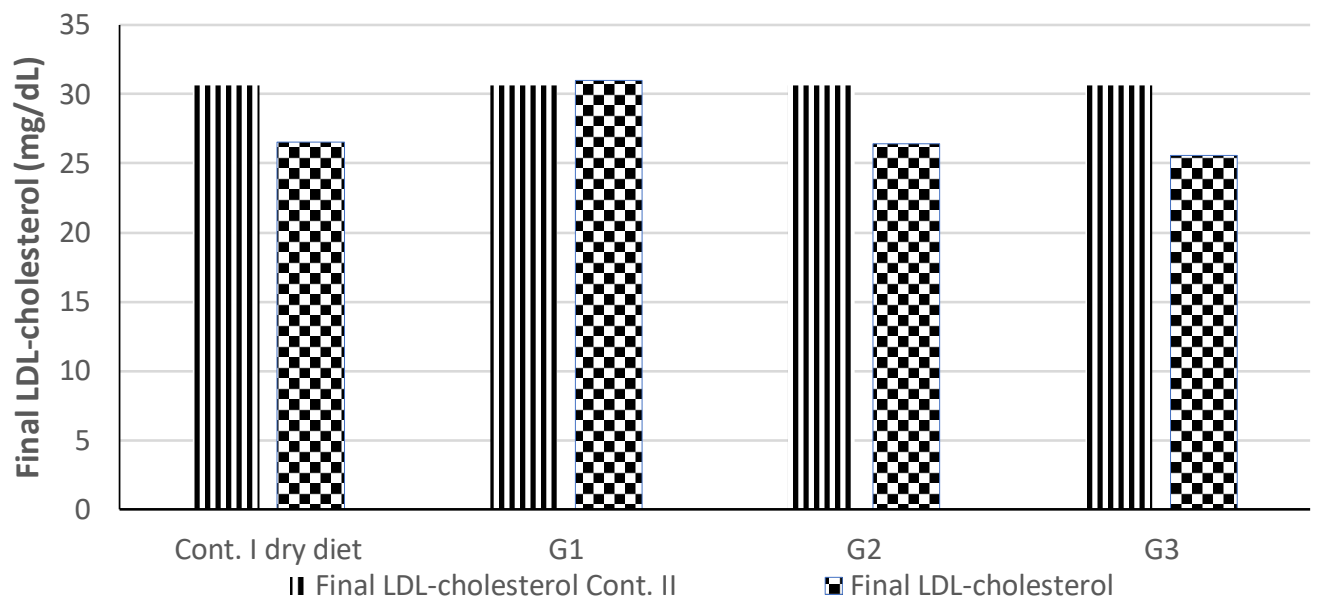

Figure 3. Effect of fed milk goats received different amounts of flaxseed oil on the levels of serum LDL-cholesterol.

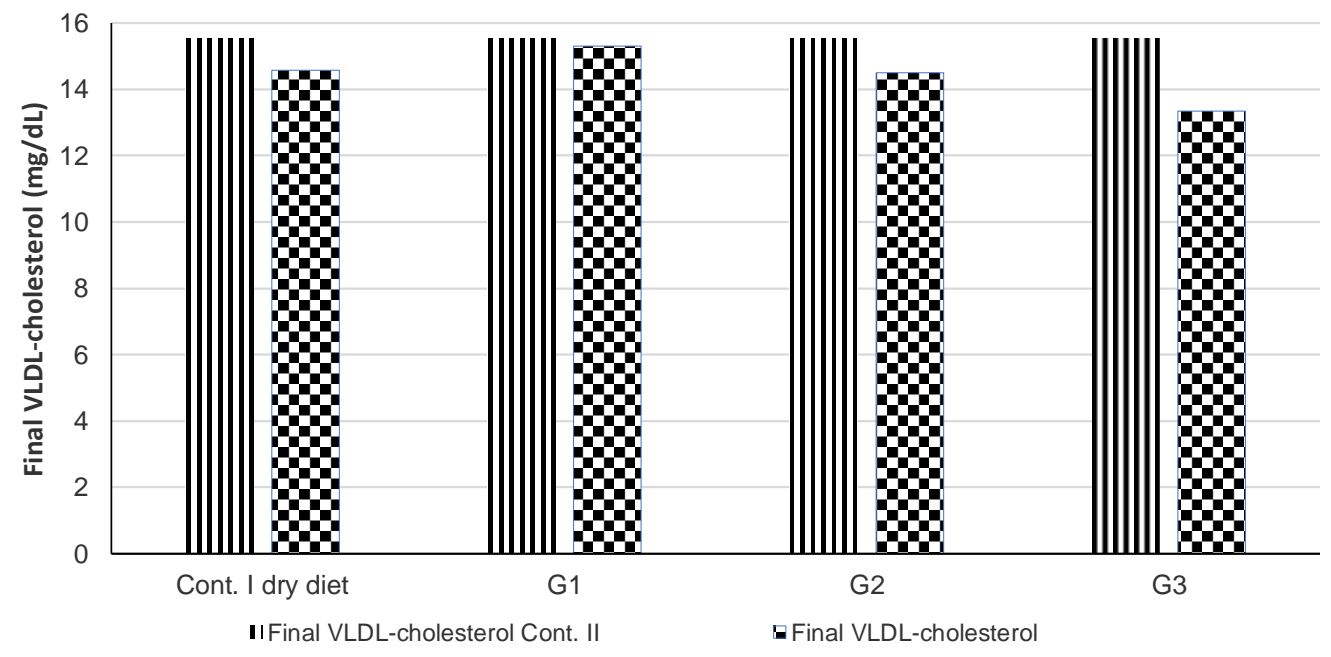

Figure 4. Effect of fed milk goats received different amounts of flaxseed oil on the levels of serum VLDL-cholesterol. 


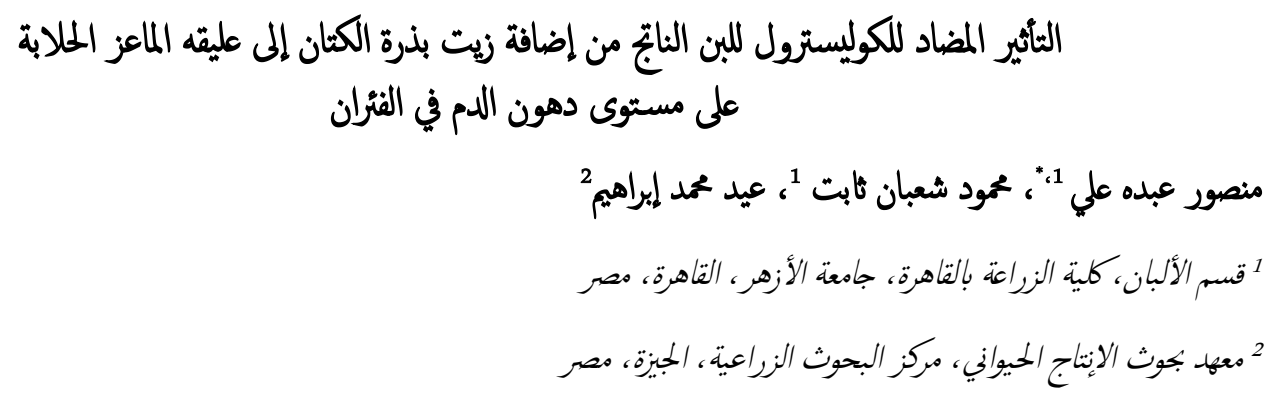

DR.Mansourabdou@azhar.edu.eg البريد الإليكتروني للباحث الرئيسي:

الملخص العربي

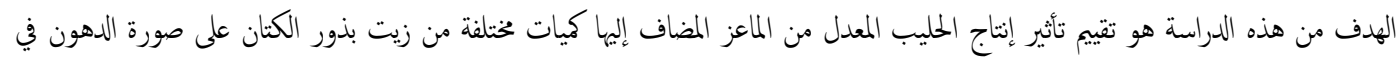

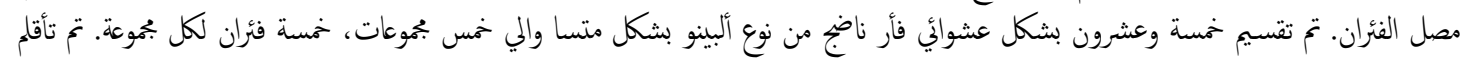

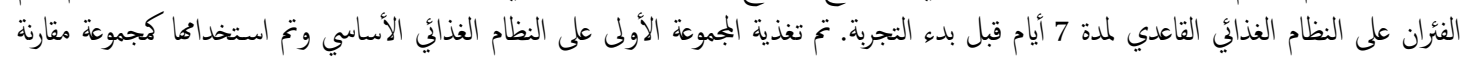

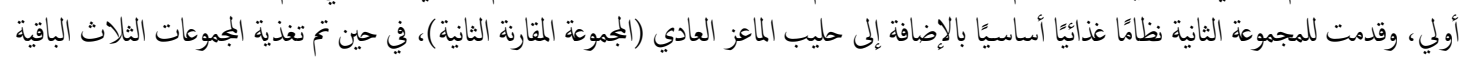

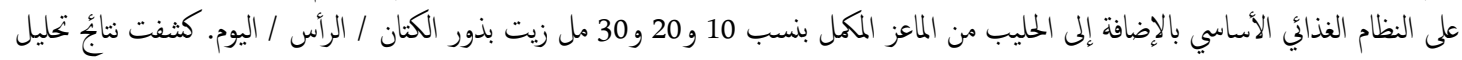

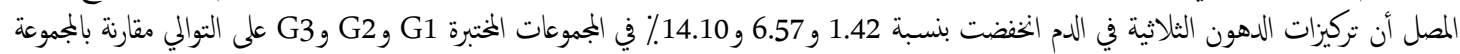

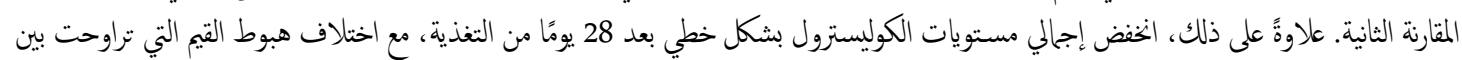

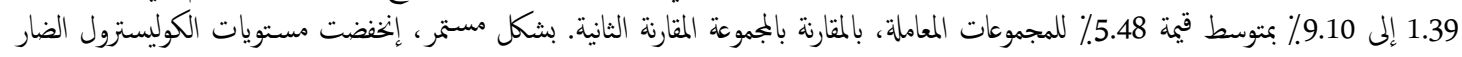

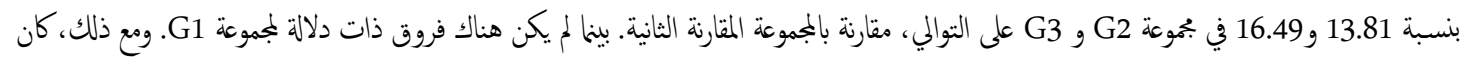

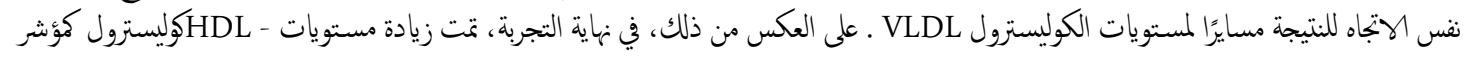

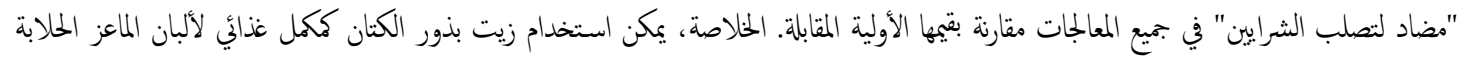

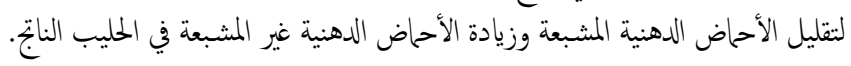
الكلمات المفتاحية: الماعز ، زيت الكنان، الكوليسترول. 